\title{
Changes in nitrogen level and mycorrhizal structure of Scots pine seedlings inoculated with Thelephora terrestris
}

\author{
Dorota HiLszcZAŃsKA*, Monika MAŁEcKA, Zbigniew SIEROTA \\ Forest Research Institute, Department of Forest Pathology, Braci Lesnej 3, Sȩkocin Stary, 05-090 Raszyn, Poland
}

(Received 8 August 2007; accepted 18 December 2007)

\begin{abstract}
-
- We investigated the influence of Thelephora terrestris, an ectomycorrhizal fungus, on the concentration of nitrogen in needles of Pinus sylvestris L. seedlings and their mycorrhizal structure within four seasons of growth.

- Seedlings were grown in four treatments: (I) inoculated $+0.030 \mathrm{~g} \mathrm{~N}$, (II) inoculated $+0.045 \mathrm{~g} \mathrm{~N}$, (III) non-inoculated $+0.030 \mathrm{~g} \mathrm{~N}$, (IV) non-inoculated $+0.045 \mathrm{~g} \mathrm{~N}$ under laboratory conditions and later planted in post-agricultural land.

- For inoculated treatments, statistically significant differences in $\mathrm{N}$ concentration of needles were observed for two- and four-year-old seedlings. The number of ectomycorrhizae and concentration of $\mathrm{N}$ in needles were negatively correlated. After four seasons of growth the greatest numbers of ectomycorrhizae were present on seedlings from treatment II, and the smallest on seedlings from treatment IV.

- Two-year-old seedlings had been colonized by at least six different fungal taxa, i.e. Cenococcum geophilum, Hebeloma crustuliniforme, Rhizopogon sp., Suillus bovinus, Thelephora terrestris and a non-identified one. Treatments I and II were dominated by the ectomycorrhizae of T. terrestris and their number was significantly greater than in treatments III or IV. On four-year-old seedlings ectomycorrhizae of T. terrestris were dominated in all treatments, while ectomycorrhizae of Hebeloma sp. were not found.
\end{abstract}

nitrogen / Scots pine / mycorrhizae / Thelephora terrestri / molecular detection

Résumé - Modifications du niveau d'azote et de la structure mycorhizienne de semis de pin sylvestre inoculés par Thelephora terrestris.

- L'influence du champignon ectomycorhizien Thelephora terrestris sur la concentration en azote dans les aiguilles de semis de pin sylvestre et sur la structure mycorhizienne des plants a été suivie durant quatre saisons de croissance.

- Les semis ont été cultivés sous quatre traitements : (I) inoculé $+0,030 \mathrm{~g} \mathrm{~N}$, (II) inoculés + 0,045 g N, (III) non inoculés + 0,030 g N, (IV) non inoculés $+0,045 \mathrm{~g} \mathrm{~N}$, dans les conditions du laboratoire avant d'être plantés sur le terrain.

- Dans les traitements d'inoculés, des différences significatives ont été observées dans la concentration des aiguilles en azote pour les semis de deux et quatre ans. Le nombre de mycorhizes et la concentration des aiguilles en azote étaient corrélés négativement. Après quatre saisons de croissance, le plus grand nombre de mycorhizes a été obtenu dans le traitement II et le plus petit dans le traitement IV.

- Les semis de deux ans avaient été colonisés par au moins six taxons différents de champignon : Cenococcum geophilum, Hebeloma crustuliniforme, Rhizopogon sp., Suillus bovinus, Thelephora terrestris et un autre taxon indéterminé. Dans les traitements I et II, les ectomycorhizes de T. terrestris dominaient et leur nombre était plus élevé que dans les traitements III et IV. Pour les semis de quatre ans, les ectomycorhizes de T. terrestris dominaient dans tous les traitements, tandis que celles de Hebeloma sp. étaient absentes.

azote / pin sylvestre / mycorhizes / Thelephora terrestris / détection moléculaire

\section{INTRODUCTION}

In Poland, the aim of the afforestation plan is to reforest about 1 million ha of soil not cultivated by farmers by 2020 (Fonder, 2002). The establishment and performance of planted tree seedlings can be significantly affected by ectomycorrhizal fungi (Dunabeitia et al., 2004; Le Tacon et al., 1994; Pera et al., 1999). Ectomycorrhizal symbiosis plays a major role in two plant processes: hydro-mineral nutrition and the portioning of $\mathrm{C}$ within the plant, with some ultimately being transferred to ectomycorrhizal fungi (Simard et al., 2002). Ectomycorrhizal plants often have higher nutrient contents than non-mycorrhizal plants, especially when grown in soils with low nutrient availability (Jones et al., 1990). According to Rousseau et al. (1992) the presence of ectomycorrhizal mycelium (including emanating elements) is strongly correlated with P nutrition in young trees.

* Corresponding author: d.hilszczanska@ibles.waw.pl
Ectomycorrhizal species, or even strains, differ with respect to their effectiveness in promoting the growth and nutrition of trees. Alongside the abundance of ectomycorrhizae, the amount and degree of differentiation of extrametrical mycelium is a very important ecological factor underpinning tree performance (Colpaert et al., 1992; Thomson et al., 1994).

Ectomycorrhizal species such as Laccaria laccata, Hebeloma crustuliniforme and Thelephora terrestris are the most common colonizers of Scots pine seedlings in bare root nurseries (Hilszczańska, 2004; Rudawska et al., 2001; Stenström, 1991; Unestam and Sun, 1995). In Poland, particularly high numbers of $T$. terrestris ectomycorrhizae have been found on seedlings originating from nurseries that have a large acreage and have been used for a long time (twenty years or more) (Kowalski, 1997; Rudawska et al., 2001). The expansionist character of T. terrestris may reflect the existence of an exploration type of extrametrical mycelium. Agerer (2001) found that $T$. terrestris is a representative of the medium-distance 
smooth exploration type, and can thus derive nutrients and water over long distances in soils.

The ubiquitous nature of the T. terrestris fungus and its numerous ectomycorrhizae on seedlings in Polish nurseries were the main factors prompting investigations as to how mycorrhization and different levels of fertilizer use change: (1) the concentration of nitrogen in seedling needles, (2) the mycorrhizal structure within four years of seedlings being planted out. The results obtained were considered likely to be helpful in estimating the advantages of artificial mycorrhization where the performance of Scots pine planted on post-agricultural land was concerned.

\section{MATERIALS AND METHODS}

\subsection{Growth of seedlings}

Seeds of Scots pine (P. sylvestris L.) were taken from the Gene Bank in Kostrzyca, Poland, and their surface sterilized for 15 min in $30 \%$ hydrogen peroxide. They were then sown in containers (Root Trainer, $\mathrm{v}=123 \mathrm{~cm}^{3}$ ) holding a previously autoclaved mixture of peat moss and vermiculite $(2: 1, \mathrm{v}: \mathrm{v})$ fertilized with Osmocote, which consisted of $47.7 \%$ ammonium and $52.6 \%$ nitrate. The $\mathrm{pH}$ of medium was 4.1. Two different nutrient supply rates of 0.030 and $0.045 \mathrm{~g} \mathrm{~N}$ per seedling were applied at the time seeds were sown. The experiment was carried out in a growth chamber with a day/night rhythm of $18 / 6 \mathrm{~h}$ and $22 / 15^{\circ} \mathrm{C}$, and at least $70 \%$ relative air humidity. Fungal isolate used to inoculation was grown on Melin-Norkrans medium (MMN) at $25{ }^{\circ} \mathrm{C}$ for 14 days. The inoculation of seedlings took place 28 days after sowing with blended mycelium of Thelephora terrestris (Erhr.) Fr. (Tt/IBL/747), each seedling receiving $5 \mathrm{~mL}$ of mycelium suspended in deionised water $(0.025 \mathrm{~g}$ of mycelium per plant). Half of the containers with seedlings were not inoculated with mycorrhizal mycelium. Seedlings were thus grown in four treatments: (I) inoculated $+0.030 \mathrm{~g} \mathrm{~N}$, (II) inoculated $+0.045 \mathrm{~g} \mathrm{~N}$, (III) non-inoculated + $0.030 \mathrm{~g} \mathrm{~N}$, (IV) non-inoculated $+0.045 \mathrm{~g} \mathrm{~N}$. Treatment III was taken to be the point of reference. Six months after inoculation, 15 seedlings from each treatment were taken for the determination of $\mathrm{N}$ concentrations in needles, as well as analysis of the degree of mycorrhizal colonization.

The following year, the beginning of spring 2004, we planted the seedlings on post agricultural land in Jablonna Forest District. Within this area, mean annual precipitation is about $522.8 \mathrm{~mm}$ and average temperature during the growing season ca. $8.4{ }^{\circ} \mathrm{C}$. The land had been abandoned for more than a 1-year period prior to our study. The site was characterized by sandy soil, corresponding to the vacciniomyrtilliosa forest type. Planting was carried out by way of a randomised block design, with four replicate blocks containing each of the four treatments (Fig. 1), as previously. Before seedlings were planted, each plot 0.0021 ha in size $(3 \mathrm{~m} \times 7 \mathrm{~m})$ was ploughed in 3 rows to ca. $12 \mathrm{~cm}$ deep with a forestry plough and 30 seedlings were planted in beds of rows with $1.5 \mathrm{~m} \times 0.7 \mathrm{~m}$ spacing. This land was 1 ha in size and the experimental plots were placed amongst the seedlings that originated from the bare-root nursery. After the first growing season (2004) and the third year (2006), samples of plants (16 per treatment - four seedlings from each replicate plot) were collected for determinations of the $\mathrm{N}$ concentrations in needles and in order to assess the presence of T. terrestris ectomycorrhizae, and the composition of the ECM communities. Samples were taken from the middle of each plot to a depth of $20 \mathrm{~cm}$.

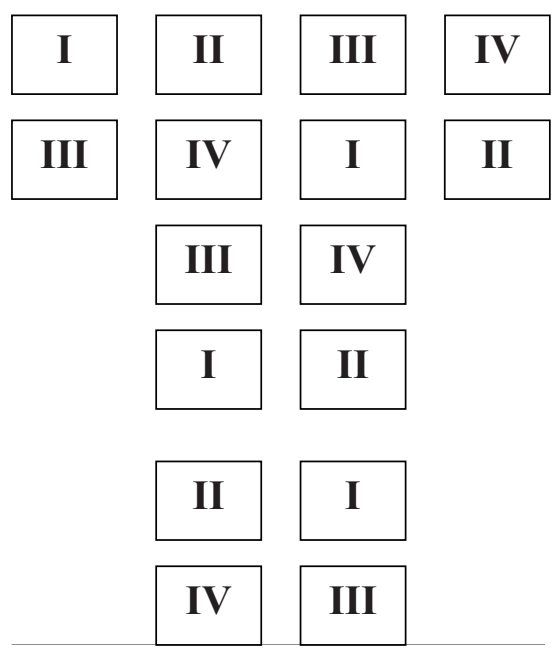

Figure 1. Planting scheme of experiment showing randomized block design of treatments: (I) inoculated $+0.030 \mathrm{~g} \mathrm{~N}$, (II) inoculated + $0.045 \mathrm{~g} \mathrm{~N}$, (III) non-inoculated $+0.030 \mathrm{~g} \mathrm{~N}$, (IV) non-inoculated + $0.045 \mathrm{~g} \mathrm{~N}$.

Table I. Mean content of minerals in soil $20 \mathrm{~cm}$ deep $\left(\mathrm{g} \times \mathrm{kg}^{-1}\right)$ and $\mathrm{pH}$.

\begin{tabular}{ccccccccc}
\hline $\mathrm{C}$ & $\mathrm{N}$ & $\mathrm{Ca}$ & $\mathrm{Mg}$ & $\mathrm{K}$ & $\mathrm{P}$ & $\mathrm{S}$ & $\mathrm{Al}$ & $\mathrm{pH}_{K C L}$ \\
\hline 8.3 & 0.85 & 1.17 & 0.67 & 0.75 & 0.63 & 0.10 & 5.55 & 4.48 \\
\hline
\end{tabular}

\subsection{Analyses}

\subsubsection{Ectomycorrhizal development}

After the first (2004) and third (2006) year, samples of plants (16 per treatment) were collected to determine the composition of the ECM communities and whether T. terrestris mycorrhizae were present. Prior to the investigation, each root system was excised from the stems and gently washed in tap water. Ectomycorrhizal tips were identified by the presence of mantle (colour, shape and surface texture), external hyphae, a slightly swollen apex and mycelial strands (Harley and Smith, 1983). Total numbers of vital mycorrhizal root tips per seedling were counted, the tips being counted and distinguished using available identification manuals (Agerer, 1987-2006; Agerer and Rambold, 2004-2007). In order to confirm that morphotyping was performed accurately, 22 mycorrhizal tips from all treatments were taken for DNA analysis with PCR RFLP method, conducted in the Institute of Biology and Biochemistry. The fungal specific primer ITS1-F (Gardes and Bruns, 1993) and universal primer ITS 4 (White et al., 1990) were used for amplification by PCR and for sequencing. DNA sequence data were compared with sequence data in the NCBI database (BLAST program, http://www.ncbi.nlm.nih.gov/). In the case of a morphotype which did not match any of those presented in cited material and the sequencing of DNA failed, was classified as unidentified. Data from sequencing are presented at Table II.

\subsubsection{Analysis of soil}

Soil samples (cores taken to a depth of $20 \mathrm{~cm}$ at 5 different locations) were collected in April 2004. Soil $\mathrm{pH}_{\mathrm{KCl}}$ and the quantities of 
Table II. Identification of the fungal symbiont on root tips of Pinus sylvestris L. seedlings.

\begin{tabular}{|c|c|c|c|}
\hline Fungal taxa & $\begin{array}{l}\text { Length of sequenced ITS (bp) } \\
\text { or brief description }\end{array}$ & $\begin{array}{l}\text { Accession No. of most similar ITS } \\
\text { sequence in Gene Bank }\end{array}$ & Identities \\
\hline Rhizopogon sp. & 760 & DQ068966 & $100 \%$ \\
\hline Cenococcum geophilum & & not sequenced & \\
\hline Hebeloma sp. & 660 & AY320386 & $99 \%$ \\
\hline Suillus bovinus & 694 & AJ272404 & $99 \%$ \\
\hline Thelephora & 541 & AF272923 & $98 \%$ \\
\hline Unidentified & $\begin{array}{l}\text { White to light red, dichotomous with rhizomorphs, mantle } \\
\text { plectenchymatous, hyphae type E, lack of clamp connections }\end{array}$ & Not sequenced & \\
\hline
\end{tabular}

ITS: Internal transcribed spacer.

Table III. Dry weight (g) of Scots pine shoots over 4 years.

\begin{tabular}{lcccc}
\hline \multirow{2}{*}{ Growth (years) } & \multicolumn{4}{c}{ Treatment** } \\
\cline { 2 - 5 } & $\mathrm{I}_{(\mathrm{LSD}=0.141)}$ & $\mathrm{II}_{(\mathrm{LSD}=0.180)}$ & $\mathrm{III}_{(\mathrm{LSD}=0.431)}$ & $\mathrm{IV}_{(\mathrm{LSD}=0.158)}$ \\
\hline 1 & $0.12 \mathrm{a}^{*} \mathrm{~A}$ & $0.09 \mathrm{aA}$ & $0.37 \mathrm{abA}$ & $0.17 \mathrm{aA}$ \\
$2_{(\mathrm{LSD}=0.112)}$ & $0.16 \mathrm{aA}$ & $0.29 \mathrm{abB}$ & $0.12 \mathrm{aA}$ & $0.29 \mathrm{aB}$ \\
4 & $0.48 \mathrm{bA}$ & $0.46 \mathrm{bA}$ & $0.75 \mathrm{~b} \mathrm{~A}$ & $0.56 \mathrm{bA}$ \\
\hline
\end{tabular}

* Different small letters within a column indicate significant differences between years according to LSD $(p<0.05)$ and ANOVA. The capital letters that are different indicate significant differences between treatments. $* * \mathrm{I}=$ Inoculated $+0.030 \mathrm{~g} \mathrm{~N}, \mathrm{II}=$ inoculated $+0.045 \mathrm{~g} \mathrm{~N}, \mathrm{III}=$ noninoculated $+0.030 \mathrm{~g} \mathrm{~N}, \mathrm{IV}=$ non-inoculated $+0.045 \mathrm{~g} \mathrm{~N}$.

the basic nutrients were determined for a one mixed sample (Tab. I). The amount of $\mathrm{N}$ was analyzed according to the Kjeldahl method, while contents of the other nutrients were identified using the ICP method (inductively coupled argon plasma spectrometer) following mineralization in a mixture of nitric and perchloric acids.

\subsubsection{Analysis of needles}

Shoots were cut off and dried at $70{ }^{\circ} \mathrm{C}$, before needles from four seedlings per treatment were collected and ground up. Needle samples were taken from four randomly selected seedlings in each treatment. The amount of $\mathrm{N}$ in each sample was analyzed using the Kjeldahl method (Kjeldahl digest with ammonia and orthophosphate read on an auto-analyzer).

\subsubsection{Statistics}

Data were analysed using Analysis of Variance in the statistical package STATISTICA (StatSoft). Prior to analysis, arcsine transformations were performed on percentages of mycorrhizae. Indication of significance is given against untransformed values. Differences amongst means were evaluated with the LSD-test (Sokal and Rolhf, 1995). A correlation between the amount of $\mathrm{N}$ in needles and the number of ectomycorrhizae was tested for using a non-parametric Spearman test.

\section{RESULTS}

The dry weight of shoot showed no significant change due to treatments except for two-year-old seedlings. The
Table IV. Total $\mathrm{N}$ content $\left(\mathrm{g} \times \mathrm{kg}^{-1}\right.$ dry weight $)$ in needles of Scots pine seedlings over 4 years of the experiment.

\begin{tabular}{lcccc}
\hline \multirow{2}{*}{ Growth (years) $)$} & \multicolumn{4}{c}{ Treatment** } \\
\cline { 2 - 5 } & $\mathrm{I}_{(\mathrm{LSD}=2.13)}$ & $\mathrm{II}_{(\mathrm{LSD}=2.81)}$ & $\mathrm{III}_{(\mathrm{LSD}=1.39)}$ & $\mathrm{IV}_{(\mathrm{LSD}=2.01)}$ \\
\hline 1 & $22.48 \mathrm{a}^{*}$ & $22.13 \mathrm{a}$ & $22.54 \mathrm{a}$ & $23.89 \mathrm{a}$ \\
2 & $19.72 \mathrm{a}$ & $18.67 \mathrm{a}$ & $19.83 \mathrm{~b}$ & $18.34 \mathrm{~b}$ \\
$4_{(\mathrm{LSD}=0.80)}$ & $12.91 \mathrm{~b}$ & $12.07 \mathrm{~b}$ & $12.90 \mathrm{c}$ & $\mathbf{1 4 . 2 0} \mathrm{c}$ \\
\hline
\end{tabular}

* Different letters within a column indicate significant differences between years according to LSD $(p<0.05)$ and ANOVA. The value printed in bold indicates significant difference between treatments in the given year.

** See Table III.

seedlings from higher $\mathrm{N}$ treatments had significantly greater shoot biomass, irrespective of inoculation (Tab. III). Differences in growth between years observed only after the last year of experiment.

After the first season (in laboratory conditions), irrespective of treatment, $\mathrm{N}$ concentrations ranged from 22.13 to $23.89 \mathrm{~g} \times$ $\mathrm{kg}^{-1}$ (Tab. IV). In all treatments, the $\mathrm{N}$ concentration in needles exceeded the range established for Scots pine seedlings (Bergmann, 1992). There was no statistically significant difference between the treatments. After second growing season the $\mathrm{N}$ concentration in needles also did not differ significantly between the treatments.

Following the planting-out of seedlings, the comparison of the $\mathrm{N}$ concentrations in the needles of four-year-old seedlings revealed statistically significant differences. For four-year-old seedlings the highest $\mathrm{N}$ concentration was present in these of treatment IV, while the lowest was observed in the needles from treatment II seedlings. Treatment IV was significantly different from all others treatments (Tab. IV, value in bold).

Seedlings from these treatments were initially grown at a higher level of $\mathrm{N}$ in the medium and seedlings in treatment II were also inoculated. Opposite relationships were noted with respect to the number of ectomycorrhizae on roots of seedlings from the treatments in question. The number of ectomycorrhizae and concentration of $\mathrm{N}$ in needles (Fig. 2) were negatively correlated $\left(r^{2}=0.7491 ; r=-0.8655 ; p=0.0000\right.$; $Y=23.8493-0.0098 * X)$.

In all treatments, the presence of ectomycorrhizae pointed to vital colonization of roots by ectomycorrhizal fungi 


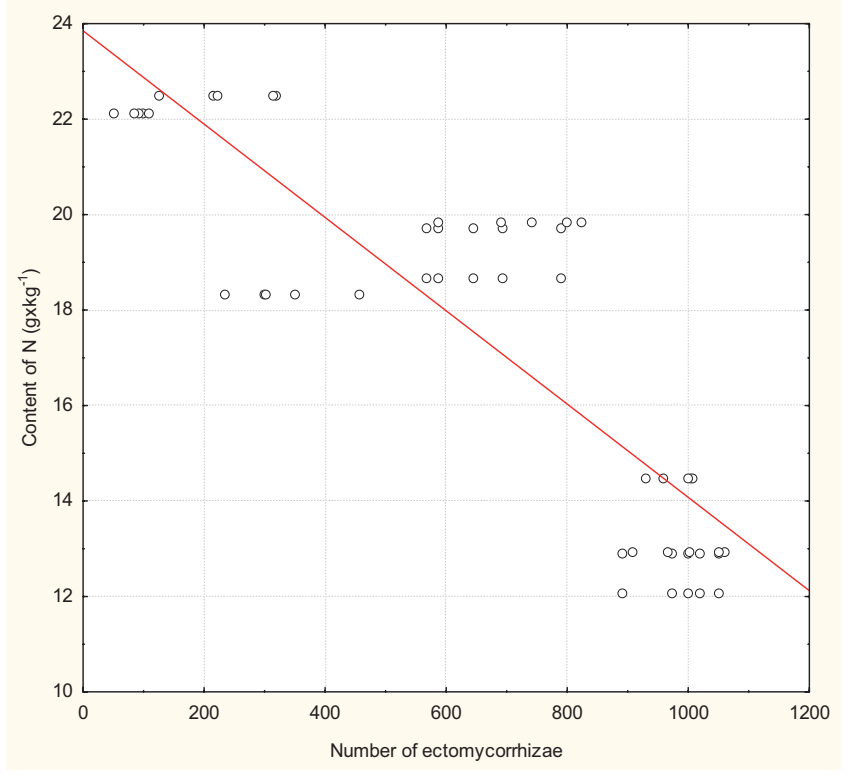

Figure 2. Correlation between total number of ectomycorrhizae and $\mathrm{N}$ concentration in needles of Scots pine ( $n=46, r=-0.87)$.

following seedling outplanting (Tab. V). Roots of two-yearold seedlings from treatment III had the greatest, and those from treatment IV the smallest number of ectomycorrhizae. Ectomycorrhizae were less numerous on the seedlings from treatments grown with an initially higher level of $\mathrm{N}$ fertilizer.

After four seasons of growth, there was no statistically significant difference in the number of ectomycorrhizae between treatments (Tab. V). Share of ectomycorrhizae of different fungal taxa changed with seedling age (Fig. 3). Two-year-old seedlings had been colonized by at least six different fungi, i.e. Cenococcum geophilum, Hebeloma sp., Rhizopogon sp., Suillus bovinus, Thelephora terrestris and an unidentified species. Treatments I and II were dominated by the ectomycorrhizae of T. terrestris (Tab. II). On four-year-old seedlings, the number of $T$. terrestris ectomycorrhizae was significantly higher than on two-year-olds with the exception of treatment I (Fig. 3). The same was true for ectomycorrhizae of S. bovinus in treatments I and II. Ectomycorrhizae created by Hebeloma sp. and C. geophilum were absent on four-year-old seedlings, their niche was replaced with mycorrhizae created by fungi from Thelephoraceae (Fig. 3).

\section{DISCUSSION}

Ectomycorrhizal abundance and seedling age were negatively correlated with $\mathrm{N}$ concentrations in needles. In the case of inoculated seedlings there was an especially strong negative correlation between numbers of ectomycorrhizae and $\mathrm{N}$ concentrations in needles $\left(r^{2}=0.8417 ; r=-0.9174 ; p=0.0000\right.$; $Y=24.5414-0.0109 * X)$. This fact may be related to the location and storage of $\mathrm{N}$ in external mycelium. The external mycelium plays a major role in the accumulation of assimilated $\mathrm{N}$, and would seem to be an important feature building fungal biomass (Wallander et al., 1999).
Table V. Mean number of ectomycorrhizal tips on Scots pine samplings over 4 years.

\begin{tabular}{lcccc}
\hline \multirow{2}{*}{ Growth (years) } & \multicolumn{4}{c}{ Treatment** } \\
\cline { 2 - 5 } & $\mathrm{I}_{(\mathrm{LSD}=106.9)}$ & $\left.\mathrm{II}_{(\mathrm{LSD}}=73.2\right)$ & $\left.\mathrm{III}_{(\mathrm{LSD}}=116.5\right)$ & $\left.\mathrm{IV}_{(\mathrm{LSD}}=92.1\right)$ \\
\hline $1_{(\mathrm{LSD}=85.8)}$ & $238 \mathrm{a}$ * A & $86 \mathrm{aB}$ & Non-inoculated & Non-inoculated \\
$2_{(\mathrm{LSD}=112.1)}$ & $656 \mathrm{bA}$ & $489 \mathrm{bB}$ & $728 \mathrm{aA}$ & $328 \mathrm{aC}$ \\
4 & $986 \mathrm{cA}$ & $1009 \mathrm{cA}$ & $996 \mathrm{bA}$ & $979 \mathrm{bA}$ \\
\hline
\end{tabular}

* Different small letters within a column indicate significant differences between years according to LSD $(p<0.05)$ and ANOVA. The capital letters that are different indicate significant differences between treatments. ** See Table III.

Nitrogen located in external hyphae and unavailable to plants is probably used in the building of chitin, structurallybound proteins, excreted enzymes (Wessels, 1993) and excreted amino acids. In culture experiments (Hobbie and Colpaert, 2003), lower rates of $\mathrm{N}$ supply were found to result in greater allocation to mycorrhizal fungi and a corresponding decrease in $\mathrm{N}$ in needles.

A concentration of $\mathrm{N}$ only half as high in mycorrhizal plants as in non-mycorrhizal ones is common in field studies at sites of low N availability (Michelsen et al., 1996; 1998; Nadelhoffer et al., 1996). It is possible that direct $\mathrm{N}$ uptake by plants is more important, in particular during the first weeks after inoculation, when the hyphal network is not yet fully developed (Hobbie and Colpaert, 2003).

In our experiment, seedlings were fertilized regularly for three months and, when exposed to higher doses of $\mathrm{N}$, gained less benefit (with respect to the number of ectomycorrhizae) than was to be noted in treatments with lower doses. Opposite results were reflected in the shoot biomass for two-year-old seedlings whereas at the first and the fourth season fertilization did not effect the growth of Scots pine seedlings (Tab. III). This is in agreement with findings of Väre (1990), who found that different doses of $\mathrm{N}$ fertilization had no effect on growth of Scots pine seedlings. Nitrogen nutrition research has always been subjected to conflicted results that may be caused by differences in the nitrogen nutrition of mycorrhizal fungal species and their isolates (Termorshuizen and Ket, 1991). Some authors found greater below-biomass of plants at low $\mathrm{N}$ availability (Colpaert et al., 1999; Raich and Nadelhoffer, 1989) but even if the below-biomass was greater there was no significant differences in the above- ground biomass (Hobbie and Colpaert, 2003).

The results of the work described here point to a positive role of $T$. terrestris in the colonization of roots following the planting-out of seedlings on former farmland. $T$. terrestris and other Thelephoraceae were observed to readily replace Hebeloma sp. and C. geophilum. Similar results were obtained by Guidot et al. (2003), in relation to the replacement of $H$. cylindrosporum ectomycorrhizae. This may suggest that these fungi are poor competitors that can only thrive in species-poor communities. Naturally, the land we studied differs in many aspects from typically forest lands. However, even in seemingly undisturbed forest ecosystems, 

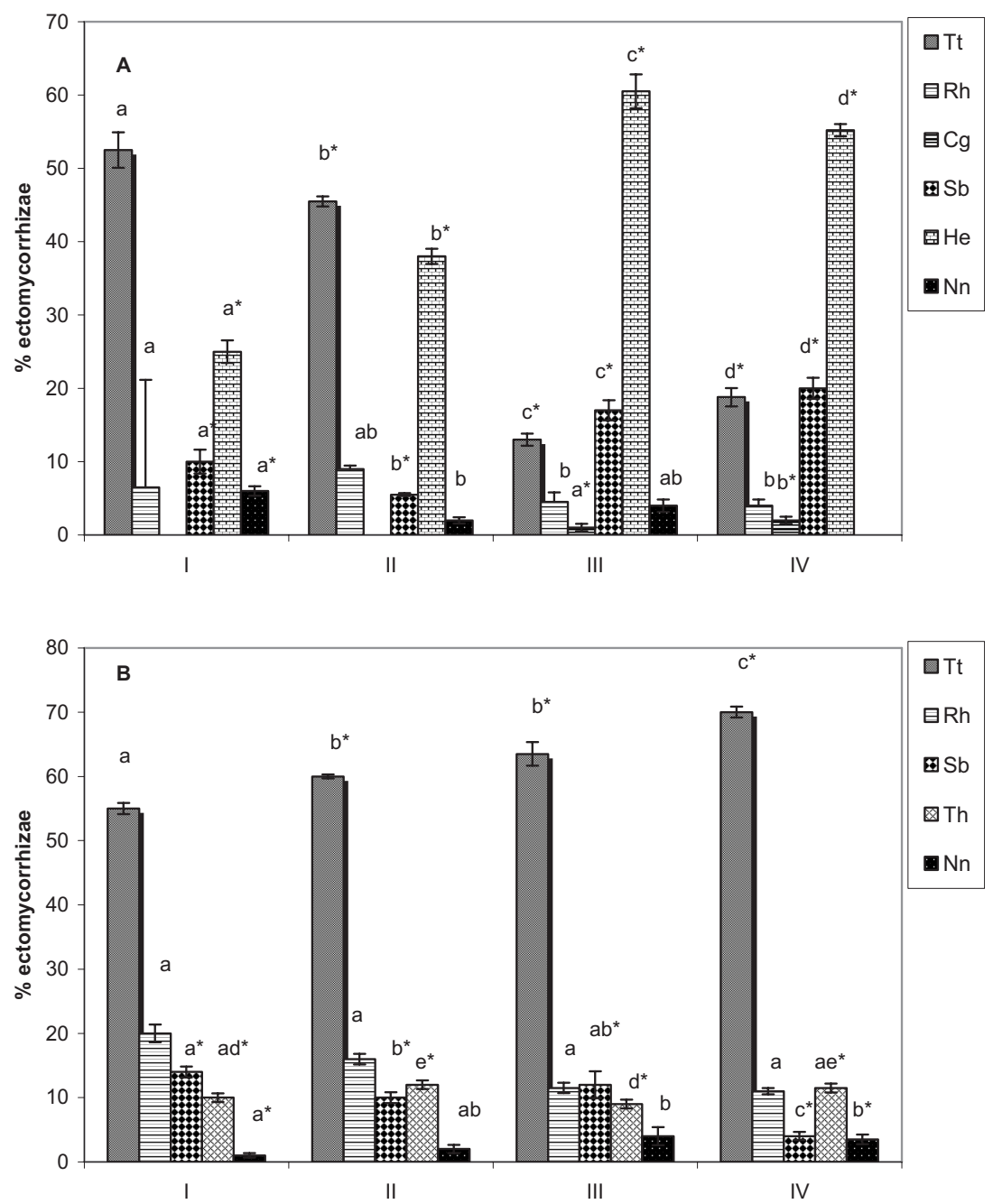

Figure 3. Ectomycorrhizal morphotypes in field treatments after: (A) two and (B) four seasons of growth: Tt, Thelephora terrestris, Rh, Rhizopogon, $\mathrm{Cg}$, Cenococcum geophilum, Sb, Suillus bovinus, He, Hebeloma, Th, Thelephoraceae, Nn, unidentified. Bars represent $( \pm)$ 1SE. Significant differences between fungi in each treatment are indicated by different letters and significant differences between years are given with $*(P<0.05)$ according to LSD tests, two-factor ANOVA (years $\times$ treatments: $\mathrm{df}=$ $21 ;$ df error $=52.24)$. the occurrence of ectomycorrhizal species, characterized by genets which form small patches of fruit bodies and only occurred during one season has also been reported (Gherbi et al., 2003; Redecker et al., 2001). Since it is known that mycorrhizae are short-lived structures, being continuously replaced by new myccorhizae on the same roots (Persson, 1979; Sanantonio and Sanantonio, 1987), it has always been implicitly assumed that the fungal species already present on roots contributed predominantly to the formation of the new mycorrhizae. Our results show that this may not always be true and that a species that occupies a significant part of the roots can be completely eliminated and replaced in the 'next generation' of mycorrhizae. The new mycorrhizae could be created by fungal species capable of rapidly colonizing empty niches, for instance, by means of spores. Such a scenario is particularly likely if mature forests are located in the vicinity of postagricultural lands. A new question thus arises regarding the consequences of this process for the further performance of seedlings.

It is still unclear if increases in $\mathrm{N}$ availability affect the fungi directly, or whether changes in community structure are mediated via the host plant. Any species which rely upon the ecto- mycorrhizal mycelium to colonise new tips and which are sensitive to increasing $\mathrm{N}$, would be at a competitive disadvantage under conditions of high $\mathrm{N}$ availability (Erland and Taylor, 2002). Moreover, is has been concluded that nitrogen deposition could alter plant community composition by changing the community of mycorrhizal fungal symbionts (Aerts, 2002; Rilig et al., 2002).

Acknowledgements: We thank Heloise Gibb for linguistic support. We are also grateful to two anonymous reviewers for their helpful comments. This study was funded by the Committee for Scientific Research under Project 3PO6L 04724.

\section{REFERENCES}

Aerts R., 2002. The role of various types of mycorrhizal fungi in nutrient cycling and plant competition. In: Heijden M.G.A. and Sanders I.R. (Eds.), Mycorrhizal Ecology, Springer, Berlin-Heidelberg -New York, pp. 117-131.

Agerer R., 1987-2006. Colour Atlas of Ectomycorrhizae. Einhorn Verlag, Schwabisch-Gmünd.

Agerer R., 2001. Exploration types of ectomycorrhizae. Mycorrhiza 11: $107-114$. 
Agerer R. and Rambold G., 2004-2007. DEEMY-An information system for characterization and determination of ectomycorrhizae, http://www.deemy.de, Munich, Ludwig Maximilians University.

Bergmann W., 1992. Nutritional disorders of plants. Gustav Fischer, Verlag Jena-Stuttgart- New York.

Colpaert J.V., Van Assche J.A., and Luijtens K., 1992. The growth of the extramatrical mycelium of ectomycorrhizal fungi and the growth response of Pinus sylvestris L. New Phytol. 120: 127-135.

Colpaert J.V., Van Tichelen K.K., Van Assche J.A., and Van Laere A., 1999. Short-term phosphorus uptake rates in mycorrhizal and nonmycorrhizal roots of intact Pinus sylvestris seedlings. New Phytol. 143: 589-597.

Dunabeitia M., Rodriguez N., Salcedo I., and Sarrionandia E., 2004. Field mycorrhization and its influence on the establishment and development of the seedlings in a broadleaf plantation in the Basque Country. For. Ecol. Manage. 195: 129-139.

Erland S. and Taylor A., 2002. Diversity of ecto-mycorrhizal fungal communities in relation to the abiotic environment. In: Heijden M.G.A. and Sanders I.R. (Eds.), Mycorrhizal Ecology, Springer, BerlinHeidelberg -New York, pp. 163-193.

Fonder W., 2002. Organizacyjne i ekonomiczne aspekty zwiększania lesistości w Polsce. Post. Nauk Rol. Vol. 49/54, No3.

Gardes M. and Bruns T., 1993. ITS primers with enhanced specifity for basidiomycetes - application to the identification of mycorrhizae and rusts. Mol. Ecol. 2: 113-118.

Gherbi H., Delaruelle C., Selosse M.A., and Martin F., 1999. High genetic diversity in a population of the ectomycorrhizal basidiomycete Laccaria amethystine in a 150-year-old beech forest. Mol. Ecol. 8: 2003-2013.

Guidot A., Debaud J.C., Effosse A., and Marmeisse R., 2003. Belowground distribution and persistence of an ectomycorrhizal fungus. New Phytol. 161: 539-547.

Harley J.L. and Smith S.E., 1983. Mycorrhizal Symbiosis, Academic Press, Toronto.

Hilszczańska D., 2004. Mycorrhizal status of Scots pine Pinus sylvestris L. seedlings grown in watered and non-watered nursery condition. Dendrobiology 52: 23-28.

Hobbie E.A. and Colpaert J.V., 2003. Nitrogen availability and colonization by mycorrhizal fungi correlate with nitrogen isotope patterns in plants. New Phytol. 157: 115-126.

Jones M.D., Durall D.M., and Linker P.B., 1990. Phosphorus relationships and production of extramatrical hyphae by two types of willow ectomycorrhizas at different soil phosphorus levels. New Phytol. 115: $259-267$.

Kowalski S., 1997. Practical aspects of mycotrophism in forest nurseries. Sylwan 6: 5-15.

Le Tacon F., Alvarez I.F., Bouchard D., Henrion B., Jackson M.R, Luff S., Parlade I.J., Pera J., Stenström E., Villeneuve N., and Walker C., 1994. Variation in field response of forest trees to nursery ectomycorrhizal inoculation in Europe. In: Mycorrhizas in ecosystems, CAB, Wallingford, pp. 119-134.

Michelsen A., Quarmby C., Sleep D., and Jonasson S., 1998. Vascular plant ${ }^{15} \mathrm{~N}$ natural abundance in heath and forest tundra ecosystem is closely correlated with presence and type of mycorrhizal fungi in roots. Oecologia 115: 406-418.

Michelsen A., Schmidt I.K., Jonasson S., Quarmby C., and Sleep D., 1996. Leaf ${ }^{15} \mathrm{~N}$ abundance of subartic plants provides field evidence that ericoid, ectomycorrhizal and non-and arbuscular mycorrhizal species access different sources of nitrogen. Oecologia 105: 53-63.

Nadelhoffer K., Shaver G., Fry B., Giblin A., Jonsson L., and McKane R., 1996. ${ }^{15} \mathrm{~N}$ natural abundances and $\mathrm{N}$ use by tundra plants. Oecologia 107: 386-394.
Pera J., Alvarez I.F., Rincon A., and Parlade J., 1999. Field performance in northern Spain of Douglas-fir seedlings inoculated with ectomycorrhizal fungi. Mycorrhiza 9: 77-84.

Persson H., 1979. Fine root production, mortality and decomposition in forest ecosystems. Vegetatio 41: 101-109.

Raich J.W. and Nadelhoffer K.J., 1989. Belowground carbon allocation in forest ecosystems: global trends. Ecology 70: 1346-1354.

Redecker D., Szaro T.M., Bowman R.J., and Bruns T.D., 2001. Small genets of Lactarius xanthogalactus, Russula cremoricolor and Amanita francheti in late-stage ectomycorrhizal successions. Mol. Ecol. 10: 1025-1034.

Rillig M., Treseder K.K., and Allen M.F., 2002. Global change and mycorrhizal fungi. In: Heijden M.G.A. and Sanders I.R. (Eds.), Mycorrhizal Ecology, Springer, Berlin- Heidelberg -New York, pp. 135-153.

Rousseau J.V.D., Reid C.C.P., and English R.J., 1992. Relationship between biomass of the mycorrhizal fungus Pisolithus tinctorius and phosphorus uptake in loblolly pine seedlings. Soil Biol. Biochem. 24: $183-184$.

Rudawska M., Leski T., and Gornowicz R., 2001. Mycorrhizal status of Pinus sylvestris nursery stock in Poland as influenced by nitrogen fertilization. Dendrobiology 46: 49-58.

Sanantonio D. and Sanantonio E., 1987. Effect of thining on production and mortality of fine roots in a Pinus radiata plantation on a fertile site in New Zealand. Can. J. For. Res. 17: 919-928.

Simard S.W., Jones M.D., and Durall D.M., 2002. Carbon and nutrient fluxes within and between mycorrhizal plants. In: Heijden M.G.A. and Sanders I.R. (Eds.), Mycorrhizal Ecology, Springer, BerlinHeidelberg -New York, pp. 34-61.

Stenström E., 1991. The effects of flooding on the formation of ectomycorrhizae in Pinus sylvestris seedlings. Plant Soil 131: 247-250.

Sokal R.R. and Rohlf F.J., 1995. Biometry, 3rd ed., Freeman and Company, San Francisco.

Termorshuizen A.J. and Ket P.C., 1991. Effects of ammonium and nitrate on mycorrhizal seedlings of Pinus sylvestris. Eur. J. For. Pathol. 21: 404-413.

Thomson B.D., Grove T.S., Malajczuk N., and Hardy G.E.S., 1994. The effectiveness of ectomycorrhizal fungi increasing the growth of Eucalyptus globulus Labill. in relation to root colonization and hyphal development in soil. New Phytol. 126: 517-524.

Unestam T. and Sun Y.P., 1995. Extramatrical structures of hydrophobic and hydrophilic ectomycorrhizal fungi. Mycorrhiza 5: 301-311.

Wallander H., Arnebrandt K., and Dahlberg A., 1999. Relationship between fungal uptake of ammonium, fungal growth and nitrogen availability in ectomycorrhizal Pinus sylvestris seedlings. Mycorrhiza 8: 215-223.

Väre H., 1990. Effect of soil fertility on root colonization and plant growth of Pinus sylvestris nursery seedlings inoculated with different ectomycorrhizal fungi. Scand. J. For. Res. 5: 493-499.

Wessels J.G.H., 1993. Wall growth, protein excretion and morphogenesis in fungi. New Phytol. 123: 397-413.

White T.J., Bruns T., Lee S., and Taylor J., 1990. Amplification and direct sequencing of fungal ribosomal RNA genes for phylogenetics. In: Innis M.A., Gefland D.H., Sninsky J., White T.J. (Eds.), PCR Protocols. A Guide to Methods and Amplifications, Academic Press, pp. 315-322. 